\title{
Mechanical Behavior of Inconel 625 at Elevated Temperatures
}

\author{
Mauro M. de Oliveira ${ }^{1,2}$, Antônio A. Couto ${ }^{1,3}{ }^{(0)}$, Gisele F. C. Almeida ${ }^{1,3, *(1)}$, \\ Danieli A. P. Reis ${ }^{4,5}{ }^{(0}$, Nelson B. de Lima ${ }^{1}$ and Renato Baldan ${ }^{6}($ i) \\ 1 Center for Materials Science and Technology, Instituto de Pesquisas Energéticas e Nucleares, São Paulo \\ 05508-000, Brazil; mauromach@gmail.com (M.M.d.O.); acouto@ipen.br (A.A.C.); nblima@ipen.br (N.B.d.L.) \\ 2 Department of Mechanical Engineering, Instituto Federal de Educação, Ciência e Tecnologia de São \\ Paulo-IFSP, São Paulo 01109-010, Brazil \\ 3 Department of Materials Engineering and Nanotechnology, Universidade Presbiteriana Mackenzie, \\ São Paulo 01302-907, Brazil \\ 4 Science and Technology Department, Universidade Federal de São Paulo-UNIFESP, \\ São José dos Campos 12231-280, Brazil; danielireis@gmail.com \\ 5 Department of Aeronautical and Mechanical Engineering, Instituto Tecnológico de \\ Aeronáutica-ITA/DCTA, São José dos Campos 12228-900, Brazil \\ 6 Department of Production Engineering, São Paulo State University (UNESP), Campus of Itapeva, \\ Itapeva 18409-010, Brazil; renatobaldan@gmail.com \\ * Correspondence: gisele.almeida@mackenzista.com.br; Tel.: +55-119-9639-8967
}

Received: 27 December 2018; Accepted: 9 February 2019; Published: 7 March 2019

\begin{abstract}
Inconel 625 is a nickel-based alloy that is mainly used in high-temperature applications. Inconel 625 exhibits an unstable plastic flow at elevated temperatures characterized by serrated yielding, well-known as the Portevin-Le Chatelier effect. The evaluation of the mechanical properties of Inconel 625 at high temperatures is the aim of this work. The tensile tests were executed in temperatures ranging from room temperature to $100{ }^{\circ} \mathrm{C}$ with strain rates of $2 \times 10^{-4}$ to $2 \times 10^{-3} \mathrm{~s}^{-1}$. The creep tests were executed in the temperature range of $600-700{ }^{\circ} \mathrm{C}$ and in the stress range of 500-600 MPa in a constant load mode. The optical and scanning electron microscopes were used for surface fracture observation. In the curves obtained at $200-700{ }^{\circ} \mathrm{C}$ the serrated stress-strain behavior was observed, which was related to the dynamic strain aging effect. The yield strength and the elongation values show anomalous behavior as a function of the test temperature. An intergranular cracking was observed for a specimen tensile tested at $500{ }^{\circ} \mathrm{C}$ that can be attributed to the decohesion of the carbides along the grain boundaries. The fracture surface of the specimen tensile tested at $700{ }^{\circ} \mathrm{C}$ showed the predominance of transgranular cracking with tear dimples with a parabolic shape.
\end{abstract}

Keywords: Inconel; high temperature; tensile test; creep; serrated; dynamic strain aging

\section{Introduction}

Between the nickel-based alloys, Inconel 625 one of the most widely used in high-temperature applications, such as in the aerospace, petrochemical, marine, and nuclear industries. This can be attributed to its excellent oxidation resistance and mechanical properties [1-3]. This superalloy is strengthened by the solid-solution-hardening effects of alloying elements such as chromium, molybdenum, niobium, and iron, and the precipitation-hardening effects of their intermetallic phases. [1].

Inconel 625 exhibits unstable plastic flow at elevated temperatures characterized by serrated yielding, well-known as Portevin-Le Chatelier (PLC) effect. This phenomenon is usually attributed to the dynamic strain ageing (DSA) [4-7]. The PLC effect is observed in many nickel-based superalloys within a certain range of deformation temperature and strain rate [8]. This phenomenon has 
a substantial effect on the mechanical properties of this material. This phenomenon could be explained by the dynamic interaction between mobile dislocation and diffusion solute atoms during plastic deformation.

The tensile and creep strength investigation is important for applications such as use in steam turbines. Yu et al. [9] suggested the Inconel 625 alloy's potential use for steam turbine casting applications to improve thermal efficiency. Another potential application of Inconel 625 could be used in the heat-exchanger tubes in micro-turbines and advanced aero-engines [10].

This work investigated the mechanical behavior of the Inconel 625 superalloy at elevated temperatures. The temperature range of the tensile tests ranged from room temperature to $1000{ }^{\circ} \mathrm{C}$ with a strain rate range of $2 \times 10^{-4}-2 \times 10^{-3} \mathrm{~s}^{-1}$. The temperature range of the creep tests was $600-700^{\circ} \mathrm{C}$, the stress range was 500-600 MPa, and they were executed in constant load mode. The serrated flow behavior was examined, the activation energy for DSA was evaluated, and the mechanical properties were correlated with the fracture modes.

\section{Materials and Methods}

The Inconel 625 alloy was received in cylindrical bars with diameters of $12 \mathrm{~mm}$ with hot forging and rolling in the longitudinal axis of the specimen along the hot working direction. The alloy has an austenitic microstructure. The chemical composition of the major elements (percentage by weight) agree with the ASTM B443-00 requirements [11]. The inductively coupled plasma optical emission spectrometry (ICP-OES) analysis was performed in an ARL equipment 3410 model (Laboratory of Analytical Chemistry of the Department of Materials Engineering, Lorena School of Engineering-EEL-USP, Lorena, Brazil) to verify the material chemical composition. Samples were prepared for microstructural characterization by silicon carbide papers grinding, alumina solution and diamond paste polishing, electrolytic etched in a $10 \%$ oxalic acid solution, and a current density of $100 \mathrm{~mA} / \mathrm{cm}^{2}$. Mechanical test specimens had machined surfaces.

The tensile tests were performed at temperatures ranging from room temperature to $1000{ }^{\circ} \mathrm{C}$ in a Universal Testing Instrument (model 4400R, Instron, São José dos Pinhais, Brazil). The specimens had diameters of $6 \mathrm{~mm}$ and gauge lengths of $30 \mathrm{~mm}$. Two K-type thermocouples (Minnesota Measurement Instruments LLC, Saint Paul, MN, USA) leaning against the reduced section were used to control the temperature. The strain rates used were $2 \times 10^{-4}-2 \times 10^{-3} \mathrm{~s}^{-1}$. The specimens were held for $30 \mathrm{~min}$ at the test temperature before the traverse movement started. The tensile test determined the yield strength at a strain offset of 0.002 (YS), the tensile strength (TS), and the elongation (EL) from the engineering stress-strain curve. For each condition tested, only one sample was used.

The creep tests were performed according to ASTM E-139-11 [12]. The elongation measures were performed using a linear variable differential displacement transducer (LVDT), (Denison Mayes Group, Leeds, UK). The temperature control was done using a K-type Cromel/Alumel thermocouple. The tests were performed in a constant load mode at 600,650 , and $700{ }^{\circ} \mathrm{C}$, and at 500, 550, and $600 \mathrm{MPa}$. A Scanning Electron Microscope (SEM) (JSM-6510, JEOL Ltd., Tokyo, Japan) was used to observe the fracture surfaces of the specimens after the tensile and creep tests in order to determine the predominant fracture mode.

\section{Results and Discussion}

\subsection{Material Characterization}

The results obtained by the ICP-OES and the ASTM requirements (B443-00) [11] are summarized in Table 1. The chemical composition was within the standard requirements. 
Table 1. The chemical composition required by the ASTM standard and obtained by the ICP-OES for the Inconel 625 alloy.

\begin{tabular}{|c|c|c|c|c|c|c|c|c|c|c|c|}
\hline & nent & $\mathrm{Ni}$ & $\mathrm{Cr}$ & Mo & $\mathrm{Nb}+\mathrm{Ta}$ & $\mathrm{Fe}$ & Mn & $\mathrm{Si}$ & $\mathrm{Ti}$ & Al & C \\
\hline wt $\%$ & $\begin{array}{l}\text { Required } \\
\text { Obtained }\end{array}$ & $\begin{array}{c}\text { Min. } 58.0 \\
\text { Balance }\end{array}$ & $\begin{array}{c}20.0-23.0 \\
21.5\end{array}$ & $\begin{array}{c}8.0 / 10.0 \\
9.4\end{array}$ & $\begin{array}{c}3.15-4.15 \\
3.6\end{array}$ & $\begin{array}{l}\text { Max. } 5.0 \\
2.5\end{array}$ & $\begin{array}{c}\text { Max. } 0.5 \\
0.25\end{array}$ & $\begin{array}{c}\text { Max. } 0.5 \\
-\end{array}$ & $\begin{array}{c}\text { Max. } 0.4 \\
0.27\end{array}$ & $\begin{array}{c}\text { Max. } 0.4 \\
0.29\end{array}$ & $\begin{array}{c}\text { Max. } 0.1 \\
0.05\end{array}$ \\
\hline
\end{tabular}

The microstructural analysis showed an austenitic microstructure formed by equiaxial grains in the transversal and longitudinal direction of the bar with a grain size of about $12 \mu \mathrm{m}$, as shown in Figure 1.

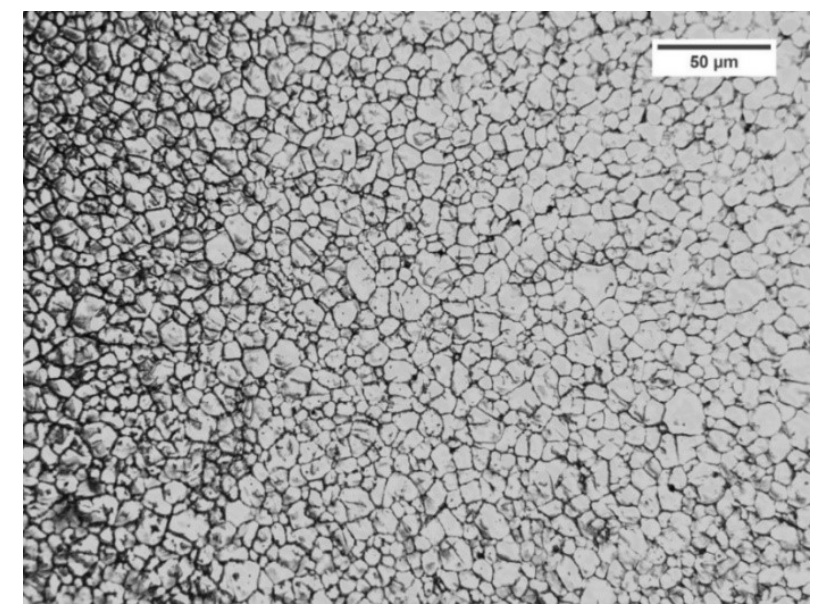

Figure 1. Optical micrograph of the longitudinal section of the bar of Inconel 625.

\subsection{Tensile Tests}

The Inconel 625 tensile tests were performed at a strain rate of $2 \times 10^{-4} \mathrm{~s}^{-1}$ in the temperature range of $23{ }^{\circ} \mathrm{C}$ (room temperature) to $1000{ }^{\circ} \mathrm{C}$. The tests results, $0.2 \%$ yield strength (YS), ultimate tensile stress (UTS), and elongation (EL) are presented in Table 2 . The tensile data were plotted in Figure 2. The yield strength values show an anomalous behavior as a function of the temperature. From the room temperature until around $600^{\circ} \mathrm{C}$, a decrease in the yield strength and a slight increase up to $700{ }^{\circ} \mathrm{C}$ occurs, decreasing sharply at temperatures above $700{ }^{\circ} \mathrm{C}$. In relation to the elongation, there is an increasing tendency with the test temperature increase. An anomaly is also present in this case at temperatures near to $600{ }^{\circ} \mathrm{C}$, where a significant decrease in the elongation occurs.

Table 2. Inconel 625 mechanical properties obtained by the tensile tests at room temperature to $1000{ }^{\circ} \mathrm{C}$.

\begin{tabular}{cccc}
\hline Test Temperature $\left({ }^{\circ} \mathbf{C}\right)$ & YS (MPa) & UTS (MPa) & EL (\%) \\
\hline 23 & 598 & 971 & 40 \\
200 & 556 & 940 & 53 \\
400 & 434 & 845 & 67 \\
500 & 473 & 829 & 61 \\
600 & 444 & 807 & 34 \\
700 & 484 & 722 & 67 \\
800 & 392 & 403 & 61 \\
900 & 195 & 199 & 61 \\
1000 & 98 & 104 & 78 \\
\hline
\end{tabular}

This anomalous behavior in the tensile properties at temperatures close to $600^{\circ} \mathrm{C}$ was also evidenced by other authors $[4,5,13-20]$ and depends on the strain rate applied in the test. According to these researches, at a strain rate less than $10^{-5} \mathrm{~s}^{-1}$, this anomalous behavior is no longer observed, resulting in a constant drop in the yield strength and a constant ductility increase with the tensile test temperature 
increase. Concerning the ultimate strength, a slight decrease occurs up to the test temperature of $600{ }^{\circ} \mathrm{C}$, and a sharp decrease in this property for temperatures above $700^{\circ} \mathrm{C}$. At $600^{\circ} \mathrm{C}$, in addition to the strain rate of $2 \times 10^{-4} \mathrm{~s}^{-1}$, tensile tests were also performed at $1 \times 10^{-3} \mathrm{~s}^{-1}$ and $2 \times 10^{-3} \mathrm{~s}^{-1}$. There were no significant differences in the mechanical properties results due to the variation of the strain rates applied. However, smaller strain rates were not tested, nor was the strain rate variation tested at other temperatures, making it impossible to compare the work of the authors mentioned above [4,5,13-20].

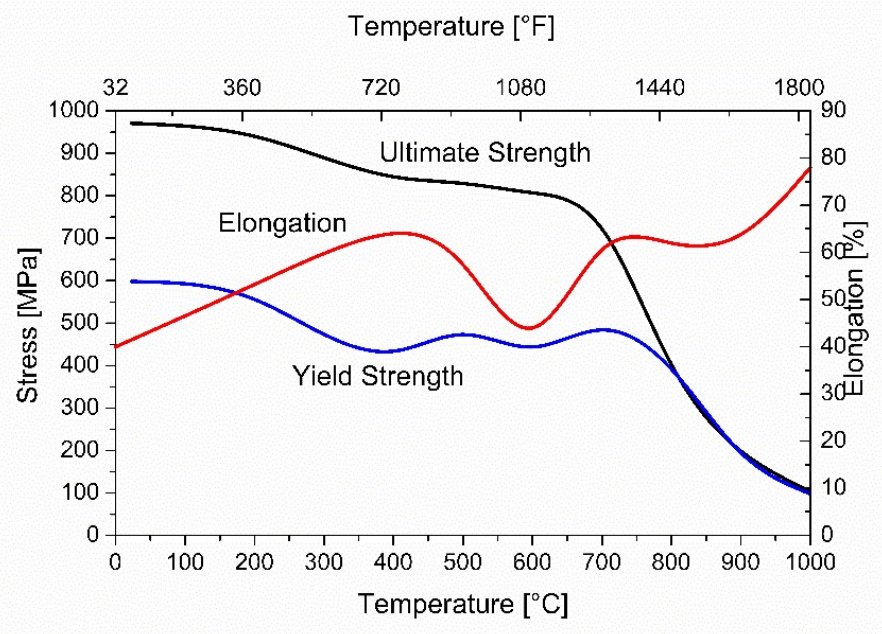

Figure 2. Yield strength, ultimate strength, and elongation results obtained from Inconel 625 tensile tests as a function of the test temperature.

The stress-strain curves obtained in the tensile tests at room temperature up to $1000{ }^{\circ} \mathrm{C}$ are shown in Figure 3. In the tensile tests executed at temperatures between 200 and $700{ }^{\circ} \mathrm{C}$ it was possible to observe a serrated curve in the region of plastic deformation in the stress-strain curves; this phenomenon is already observed in numerous works on nickel alloys $[14,19]$. Serrations are explained as fluctuations in a repeated and systematic way of the stress in the strain [21]. This type of plastic instability manifested in many metals is called the Portevin-Le Chatelier (PLC) effect [22]. The most accepted mechanism for the formation of the serrations is the dynamic strain aging (DSA) during the plastic deformation. This is a result of the interaction among solute atoms and mobile dislocations [8,21]. An acoustic emission can be heard in each stress drop which matches with the formation of a deformation band [17]. In the tensile tests at $700{ }^{\circ} \mathrm{C}$, the serrations occurred only in the initial region of plastic deformation in the stress-strain curve. In the tests above $800{ }^{\circ} \mathrm{C}$, this serrated-flow behavior was not observed.

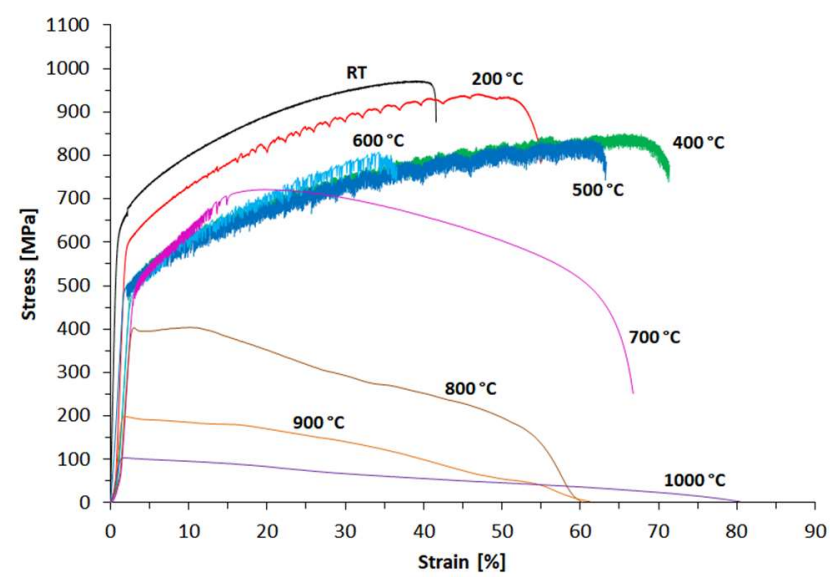

Figure 3. Stress-strain curves obtained from Inconel 625 tensile tests at room temperature (RT) until $1000^{\circ} \mathrm{C}$. 
Hale et al. [14] have associated the serration flow behavior in Ni-based superalloys at lower temperatures to the interstitial solute diffusion, such as that of carbon, and at higher temperatures, the substitutional atoms diffusion, such as that of molybdenum and chromium. [4,6,23]. Cottrell [22] was the first to suggest the dislocation-solute atom interaction model. This theory is about the interaction between mobile dislocations and diffusing solute atoms and is followed by several authors [24-35]. The type of serration can vary with the strain rate and the temperature [1]. According to some authors, the serrations can be identified by A, B, and C types [14,36,37]. The serrations do not occur randomly. From a detailed inspection, it can be possible to observe form identifiable patterns which, under specific conditions, show determined regularity [8]. At high strain rates and low temperatures, the A-type serrations occurs. At medium to high strain rates, the B-type serrations are present and appear in correlated bands. At low strain rates and high temperatures, the C-type serrations occur, and they are more regular $[8,14,21]$.

Details of the plastic strain region of the stress-strain curves acquired in the tensile tests at room temperature, 200, 300, and $500{ }^{\circ} \mathrm{C}$ are shown in Figure 4. Note that even at room temperature, a slight oscillation in stress occurs. However, this oscillation has a much smaller amplitude when compared to the serration observed in the test at $500{ }^{\circ} \mathrm{C}$. The stress-strain curve at $200{ }^{\circ} \mathrm{C}$ showed an A-type serration, while at the $500{ }^{\circ} \mathrm{C}$ the B-type serrated was observed. This B-type serration appeared in the test temperature range between 400 and $700{ }^{\circ} \mathrm{C}$. In the tensile tests at $300{ }^{\circ} \mathrm{C}$, a transition appears to occur, with serrated A + B-type. The predominance of A and B-type serrations in the tensile test curves at high strain rates and low temperatures are consistent with previous works $[8,14,19-21]$. $\mathrm{A}$ and B-type serrations are related to the diffusion of $\mathrm{C}$ atoms in Ni-based alloys [14]. The C-type serration was not found in the stress-strain curves. It should only appear in tests performed at higher temperatures and lower strain rates which were not used in this work.

Figure 5 shows the stress-strain curves of the Inconel 625 tensile tested at $600{ }^{\circ} \mathrm{C}$ and strain rates of $2 \times 10^{-4}, 1 \times 10^{-3}$ and $2 \times 10^{-3} \mathrm{~s}^{-1}$. For the curves with strain rates of $2 \times 10^{-3}$ and $2 \times 10^{-4}, 50$ and $100 \mathrm{MPa}$ were subtracted respectively, generating a vertical deviation of the curves for a clear comparison of the PLC effect behavior. Higher strain rates induced a lower frequency and lower amplitude. The lower strain rate results in a longer time for the dislocations to overcome the obstacles. Therefore, the serrations magnitude is increased, resulting in the change in the serration type. The strain rate sensitivity $(m)$ was determined in tensile tests at the same temperature and at varying strain rates. The stress corresponding to $5 \%$ of plastic strain in the tensile tests at a temperature of $600{ }^{\circ} \mathrm{C}$ was adopted for the determination of the strain rate sensitivity. The strain rate sensitivity was obtained using the following expression:

$$
m=\log \left(\sigma_{2} / \sigma_{1}\right) / \log \left(\dot{\varepsilon}_{2} / \dot{\varepsilon}_{1}\right),
$$

where $\sigma_{1}$ is the stress corresponding to $5 \%$ of the plastic strain in the tensile tests at a temperature of $600{ }^{\circ} \mathrm{C}$ and strain rates of $2 \times 10^{-3} \mathrm{~s}^{-1}$, and $\sigma_{2}$ is the stress corresponding to $5 \%$ of plastic strain in the tensile tests at a temperature of $600{ }^{\circ} \mathrm{C}$ and strain rates of $2 \times 10^{-4} \mathrm{~s}^{-1}$. The strain rates $\dot{\varepsilon}_{1}$ and $\dot{\varepsilon}_{2}$ are $2 \times 10^{-3} \mathrm{~s}^{-1}$ and $2 \times 10^{-4} \mathrm{~s}^{-1}$ respectively.

The strain rate sensitivity obtained, $m$, was -0.02 . The value is similar to that obtained by Nagesha [23]. The PLC effect occurs when the strain rate sensitivity becomes negative. This phenomenon is associated with the appearance of plastic instabilities in the uniaxial deformation $[5,8,14,17,23]$. 


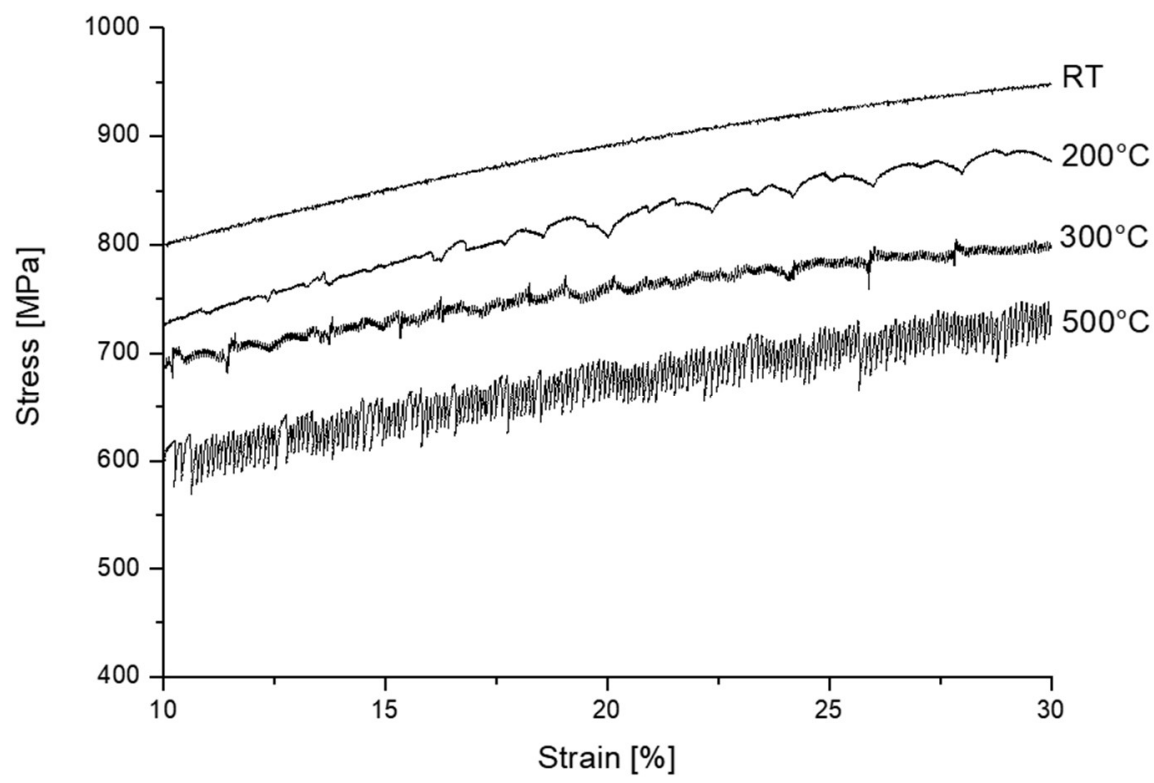

Figure 4. Details of the plastic strain region of the stress-strain curves obtained in the Inconel 625 tensile tests at room temperature, 200,300 , and $500{ }^{\circ} \mathrm{C}$.

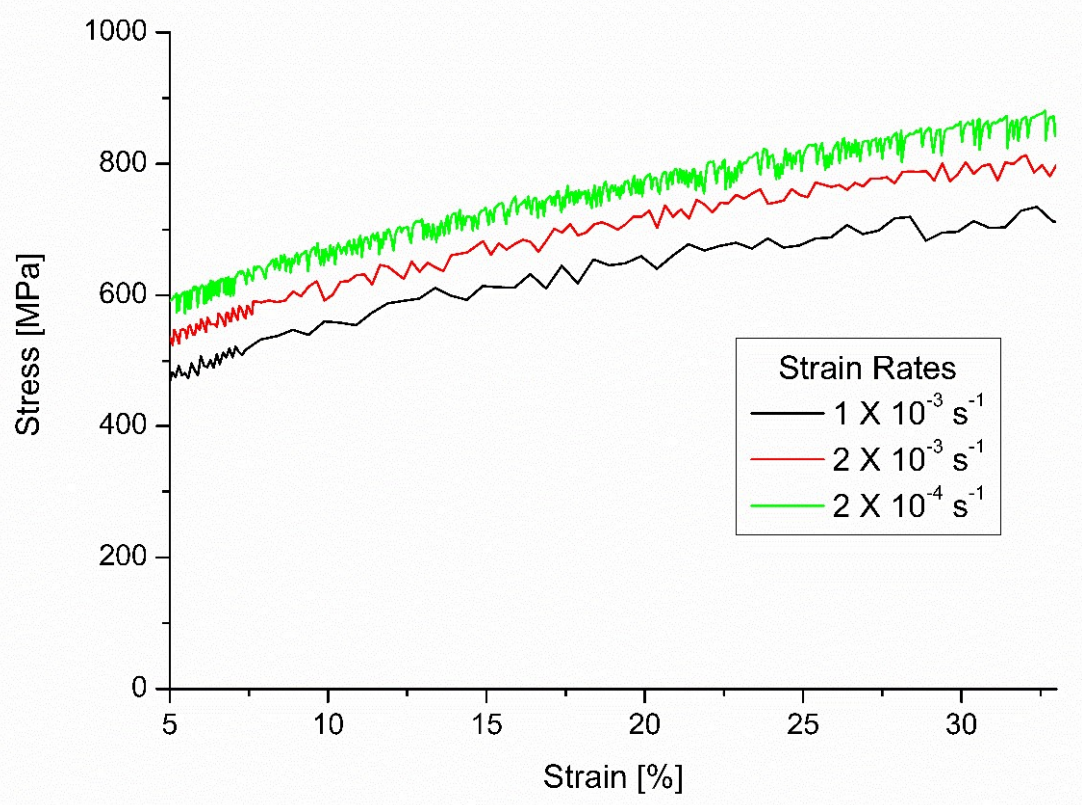

Figure 5. Details of the stress-strain curves obtained in the Inconel 625 tensile tests at $600{ }^{\circ} \mathrm{C}$ varying the strain rate. For the curves with strain rates of $2 \times 10^{-3}$ and $2 \times 10^{-4}, 50$ and $100 \mathrm{MPa}$ were subtracted respectively, generating a vertical deviation of the curves for a clear comparison of the PLC effect behavior.

Longitudinal sections of tensile fracture for the specimens tested at (a) 500 and (b) $800{ }^{\circ} \mathrm{C}$ in low magnification micrographs are shown in Figure 6. In the specimen tested at $500{ }^{\circ} \mathrm{C}$ it can be noted that the fracture occurred in a macroscopic plane inclined at $45^{\circ}$ to the tensile axis. This fracture type occurred systematically in all specimens in which the PLC effect was observed on the stress-strain curve, which led to plastic instabilities (serrated) in plastic strain until the fracture. In tensile tests at temperatures above $700{ }^{\circ} \mathrm{C}$, the PLC effect no longer occurred, and the specimens also no longer ruptured at $45^{\circ}$ to the tensile axis, as can be seen in the Figure $6 \mathrm{~b}$. This specific mode of failure caused 
by extensive shearing on a macroscopic plane inclined $45^{\circ}$ to the tensile axis had already been observed by Fournier et al. [17].

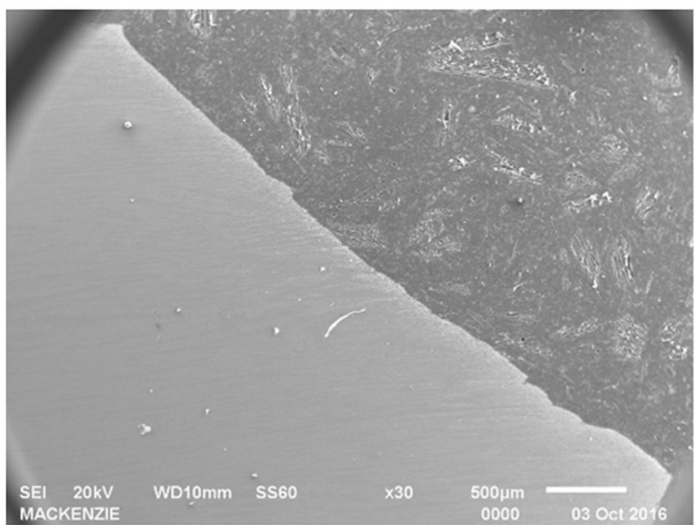

(a)

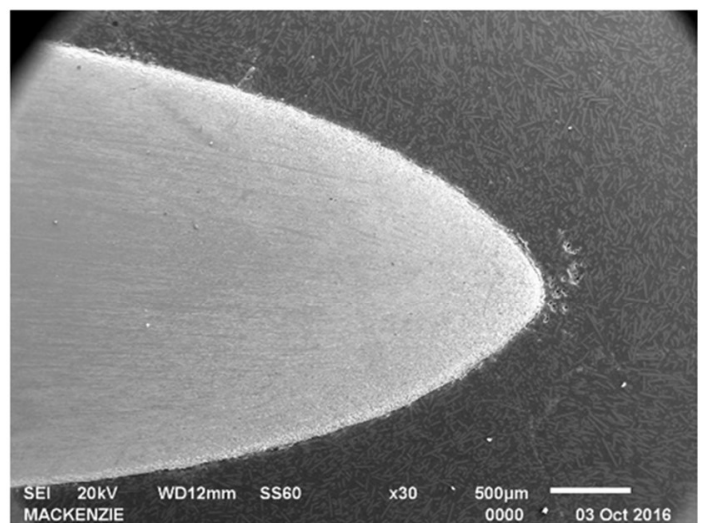

(b)

Figure 6. Micrographs of the longitudinal sections of tensile fracture for the Inconel 625 specimens tested at (a) 500 and (b) $800{ }^{\circ} \mathrm{C}$.

A detail of the longitudinal section of the fracture region of the specimen tensile tested at $500{ }^{\circ} \mathrm{C}$ is shown in Figure 7a. In this figure, an intergranular cracking is observed that can be attributed to the precipitation of carbides at grain boundaries. The decohesion of the carbides along the grain boundaries is responsible for the crack nucleation [17]. The fracture surface of this specimen is shown in Figure $7 \mathrm{~b}$, with the arrow indicating the intergranular cracking. Grain boundaries cracks were extensively observed throughout the fracture surface in specimens tested at this temperature. However, in this fractography is also observed the formation of cavities on the entire fracture surface, typical of ductile fracture. Shankar and Han [1,4] also observed similar fracture surfaces in tensile test specimens at these temperatures.

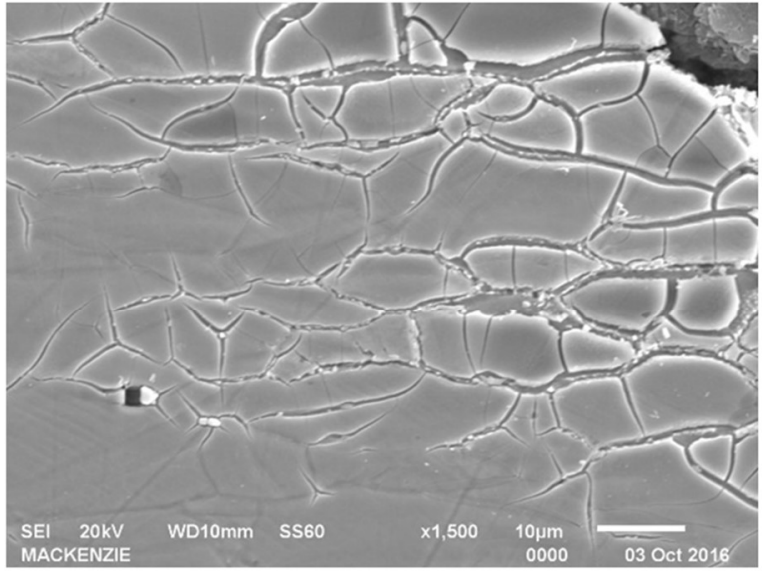

(a)

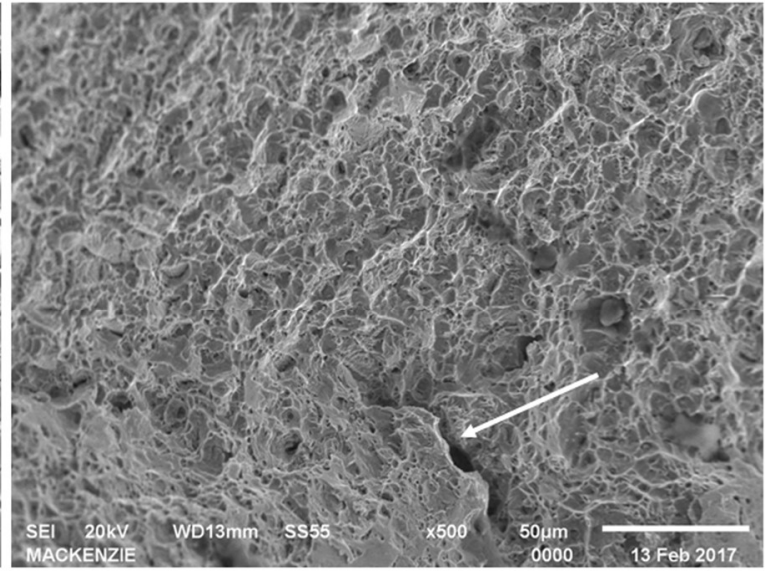

(b)

Figure 7. Micrographs of (a) the detail of the longitudinal section of the Inconel 625 fracture region tensile tested at $500{ }^{\circ} \mathrm{C}$ and (b) fracture surface of this specimen with the arrow indicating intergranular cracking.

Figure 8 shows the micrographs of the specimens tensile tested at (a) $600{ }^{\circ} \mathrm{C}$ and at (b) $700{ }^{\circ} \mathrm{C}$ in the region close to the fracture. A considerable unmodified grain size can be seen in these micrographs, but with an elongation in the tensile direction as indicated by the arrows. More elongated grains are observed in the specimen tested at $700{ }^{\circ} \mathrm{C}$. 


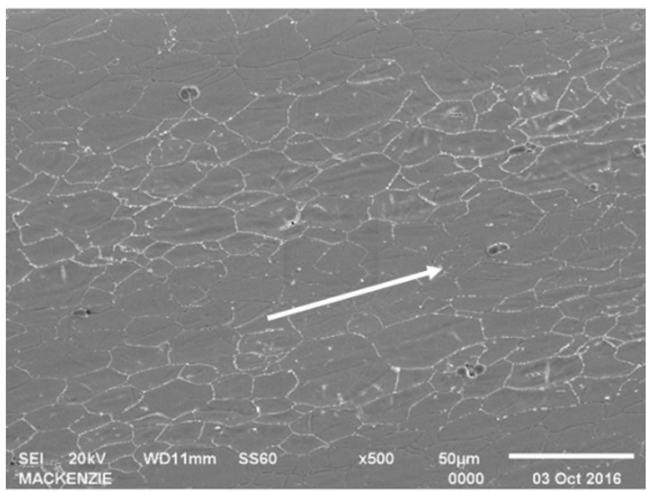

(a)

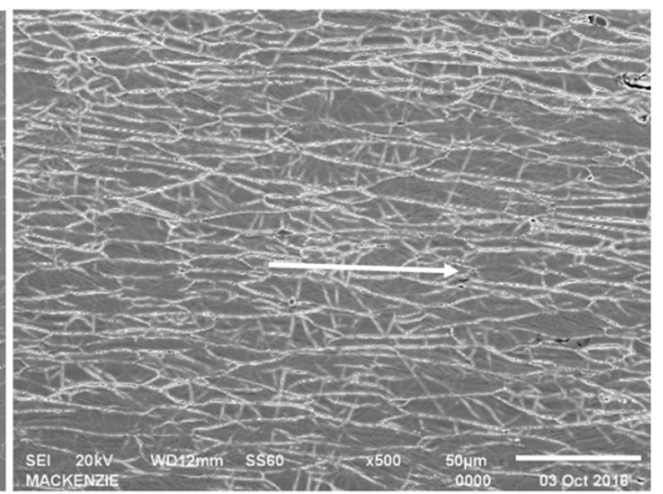

(b)

Figure 8. Micrographs of the longitudinal section of the Inconel 625 specimens tensile tested at (a) $600{ }^{\circ} \mathrm{C}$ and at (b) $700{ }^{\circ} \mathrm{C}$ in the region close to the fracture ( $3 \mathrm{~mm}$ to the fracture). The arrows are indicating the tensile test direction.

The fracture surface of the specimen tensile tested at $700{ }^{\circ} \mathrm{C}$ is shown in Figure 9 . Note the predominance of transgranular cracking with tear dimples with parabolic shape. The typical fracture surface of the tensile test specimen at these temperatures is shown in Figure 10a. Slip bands are observed in the region in evidence, also seen by Hrutkay [13]. In Figure 10b several slip lines can be seen inside the grains. The slip bands are formed during the plastic strain when strain-hardening occurs and may be responsible for a lower ductility. Note also the presence of carbides along the grain boundaries in both conditions [4].

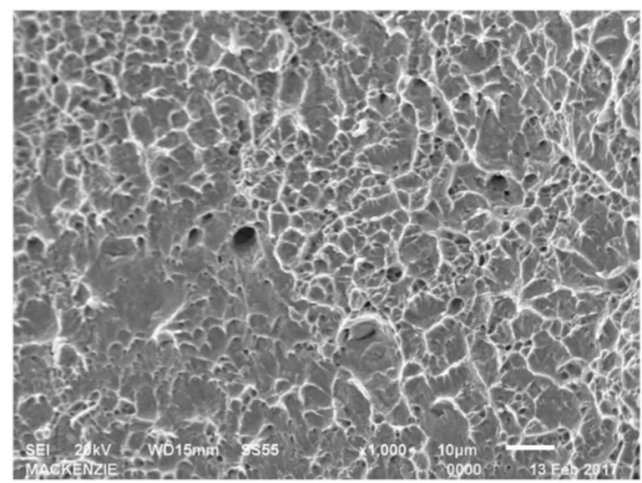

Figure 9. Micrographs of the Inconel 625 fracture surface tensile tested at $700{ }^{\circ} \mathrm{C}$ showing transgranular cracking with tear dimples.

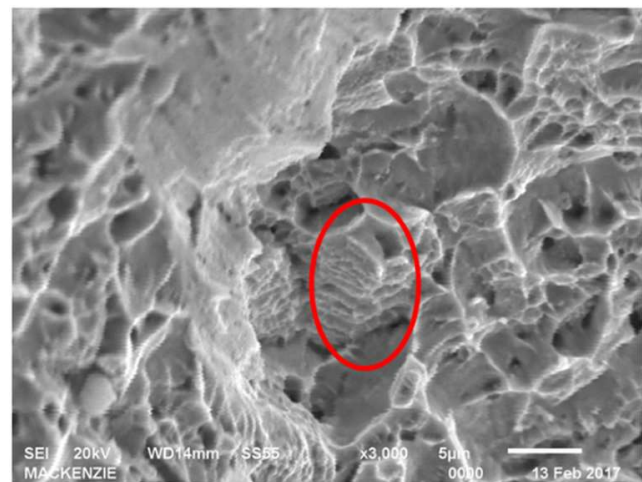

(a)

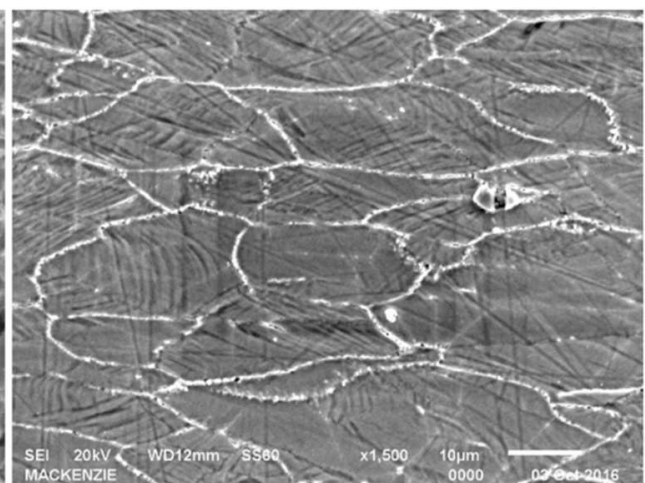

(b)

Figure 10. Micrographs of the Inconel 625 tensile tested at $700{ }^{\circ} \mathrm{C}$ : (a) typical fracture surface with slip bands in evidence and (b) longitudinal section of fracture region ( $3 \mathrm{~mm}$ to the fracture). 
The longitudinal section of the fracture region of a specimen tensile tested at $800{ }^{\circ} \mathrm{C}$ is shown in Figure 11. In this figure is observed the presence of equiaxial smaller grains, probably derived from the dynamic recrystallization. It was not possible to observe the presence of carbides in the grain boundaries. The similar microstructure was observed in the specimens tested at 900 and $1000{ }^{\circ} \mathrm{C}$. The fracture surfaces of specimens tested at temperatures above $700^{\circ} \mathrm{C}$ could not be analyzed due to the practically nonexistent fracture area, as shown in Figure $6 \mathrm{~b}$.

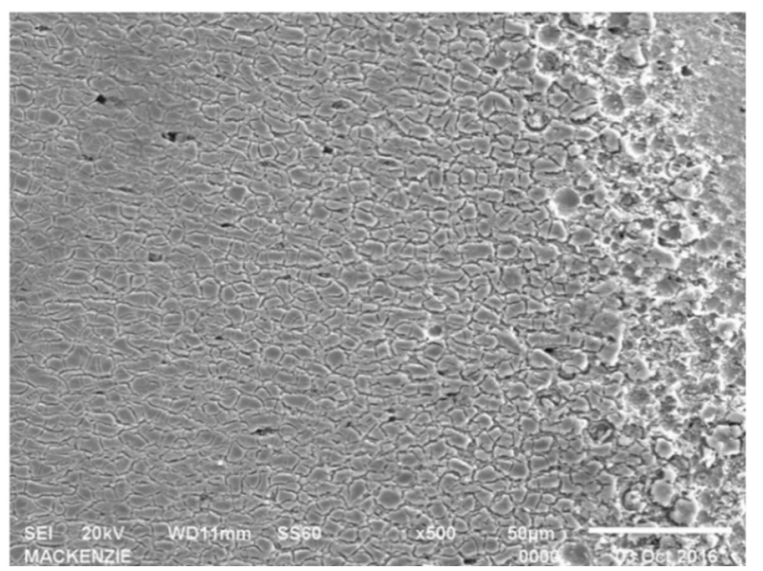

Figure 11. Micrograph of the longitudinal section of the Inconel 625 fracture region tensile tested at $800^{\circ} \mathrm{C}$ showing equiaxial grains.

\subsection{Creep Tests}

The results of the short-term creep tests performed on the Inconel 625 specimens under a constant load are summarized in Table 3, where they are presented with the primary creep time (tp), the and secondary creep rate $\left(\dot{\varepsilon}_{\mathrm{s}}\right)$. Due to the long time to reach the fracture of this material, the tests were interrupted at determined times for each condition of temperature and stress.

Table 3. Creep data of the Inconel 625.

\begin{tabular}{cccc}
\hline Temperature $\left({ }^{\circ} \mathbf{C}\right)$ & $\boldsymbol{\sigma} \mathbf{( M P a})$ & $\boldsymbol{t p}(\mathbf{h})$ & $\dot{\varepsilon}_{\mathbf{s}}(1 / \mathbf{h})$ \\
\hline 600 & 500 & 235.5 & $1.78 \times 10^{-6}$ \\
\hline \multirow{2}{*}{650} & 500 & 23.6 & $1.32 \times 10^{-4}$ \\
& 550 & 12.5 & $3.74 \times 10^{-4}$ \\
& 600 & 10.0 & $1.13 \times 10^{-3}$ \\
\hline 700 & 500 & 17.1 & $5.39 \times 10^{-4}$ \\
\hline
\end{tabular}

The Figure 12 shows the creep curve obtained at $650{ }^{\circ} \mathrm{C}$ and $500 \mathrm{MPa}$, corresponding to true strain $\dot{\varepsilon}$ as a function of the time $t$. The constant loading was applied in the vertical direction. This test was interrupted after $75 \mathrm{~h}$ without breaking. From the tests results was calculated the stress exponent $(n)$ and the creep activation energy $(Q c)$. Figure 13 shows the logarithmic relationship curve between steady creep rates and stress at $650{ }^{\circ} \mathrm{C}$ of the Inconel 625 alloy. The value of the stress dependence of the steady-state creep rate $(n)$ can be described by the power-law creep equations using standard regression techniques [38]:

$$
\dot{\varepsilon}_{\mathrm{s}}=B \sigma^{n}
$$

where $B$ is a structure-dependent constant and $\sigma$ is the applied stress.

The Figure 14 shows the logarithmic relationship between steady creep rates and inverted absolute temperature at $500 \mathrm{MPa}$. The values of the creep activation energy $(Q c)$ can be described by the Arrhenius's Law using standard regression techniques [38]:

$$
\dot{\varepsilon}_{\mathrm{s}}=B_{0} \sigma^{n} \exp \left(-Q_{\mathrm{c}} / \mathrm{R} T\right)
$$


where $B_{0}$ is a structure-dependent constant, $\sigma$ is the applied stress, $R$ is the ideal gas constant, and $T$ is the test temperature.

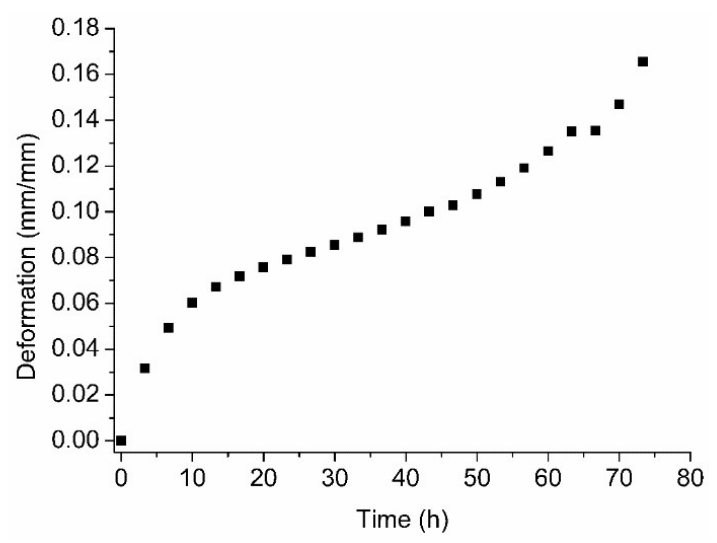

Figure 12. Creep curve of the Inconel 625 alloy at $650{ }^{\circ} \mathrm{C}$ and $600 \mathrm{MPa}$.

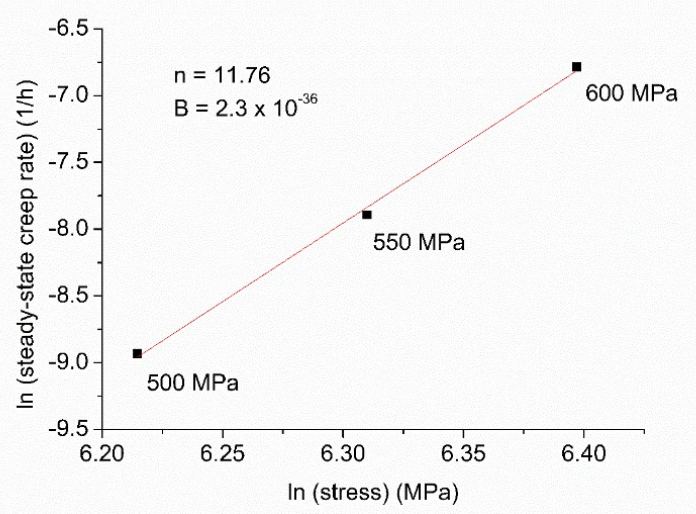

Figure 13. Steady-state creep rate dependence with the stress applied at $650{ }^{\circ} \mathrm{C}$ of the Inconel 625 alloy.

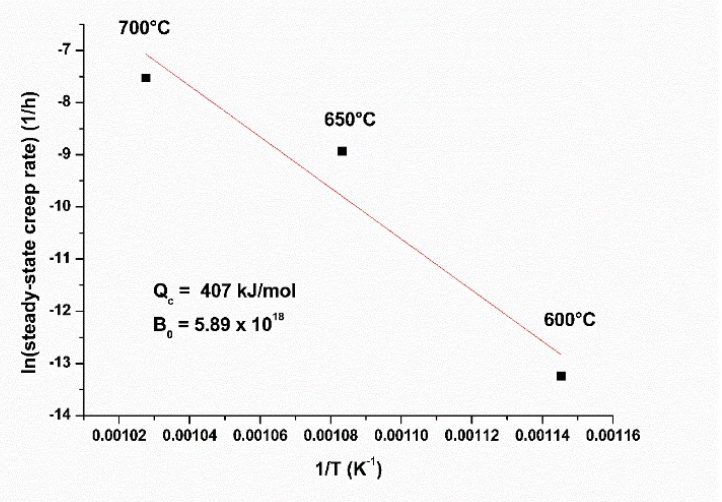

Figure 14. The diagram to calculate the activation energy (Qc) at $500 \mathrm{MPa}$ of the Inconel 625 alloy.

The value of core diffusion activation energy $\left(Q_{(\text {(core) }}\right)$ for Nickel reported from Frost and Ashby [39] was $170 \mathrm{~kJ} / \mathrm{mol}$. Moore et al. [40] found different values of self-diffusion activation energy for the Inconel 625 alloy according to the temperature. The value of the activation energy obtained for Moore et al. [40] was $108.3 \pm 6.6 \mathrm{~kJ} / \mathrm{mol}$ above $700{ }^{\circ} \mathrm{C}$ and $46.6 \pm 12.2 \mathrm{~kJ} / \mathrm{mol}$ below $650{ }^{\circ} \mathrm{C}$. Between $650-700{ }^{\circ} \mathrm{C}$, a significantly higher value of the activation energy of $527.7 \pm 23.1 \mathrm{~kJ} / \mathrm{mol}$ was found. This result was attributed to a high driving force, and the solute operating within the alloy stopped the grain boundary migration process. The activation energy value found in this work was $407 \mathrm{~kJ} / \mathrm{mol}$. This higher 
value obtained at the same temperature as Moore et al. [40] may be related to the DSA effect present in Inconel 625.

For tests performed at temperatures around $40-70 \%$ of the melting point $\left(1290-1350{ }^{\circ} \mathrm{C}\right)$ under intermediate or high stress levels, the $n$ values larger than three and the activation energy for creep $(Q c)$ values near the core diffusion activation energy $\left(Q_{(\text {core })}\right)$ suggest that the dominant creep mechanism is the dislocation creep according to Evans and Wilshire [38]. The values of $n=11.76$ and $Q_{c}=407 \mathrm{~kJ} / \mathrm{mol}$ found in this work agree with these conditions.

Caliari et al. [41] also suggested that the creep mechanism of Inconel 718 that was double aged and tested at $650-700{ }^{\circ} \mathrm{C}$ and $510-700 \mathrm{MPa}$ is controlled by the interaction of dislocations with the precipitates. Rodriguez et al. [42] found for cyromilled Inconel 625 alloy tested at $650{ }^{\circ} \mathrm{C}$ and $207 \mathrm{MPa}$ a value of activation energy for creep of $385 \mathrm{~kJ} / \mathrm{mol}$. The fact of this value exceeds the value of the activation energy for self-diffusion in $\mathrm{Ni}$, that is, $287 \mathrm{~kJ} / \mathrm{mol}$, was explained by the deformation during the creep of the second phase particles in the matrix. Sun et al. [43] attributed the formation of $\alpha-\mathrm{Cr}$ precipitation in a Ni-Fe-based alloy as obstacles to the dislocation motions during the creep process. Moreover, an increase in the Inconel 617 creep resistance at temperatures near $800{ }^{\circ} \mathrm{C}$ was attributed to solution strengthening caused by the addition of cobalt and molybdenum and the precipitation strengthening of $\mathrm{M}_{23} \mathrm{C}_{6}$ carbides [15].

In order to understand the effect mechanism of the PLC, several methods can be used to calculate the activation energy of the serrated flow $[4,14]$. The amount of activation energy can vary greatly depending on the method used to evaluate it. Moreover, these values are altered with the strain rate and the temperature, which could notably influence the serrated flow activation energy. Therefore, it is difficult to make any association related to these values.

\section{Conclusions}

The study of the mechanical behavior of Inconel 625 at elevated temperatures allowed us to conclude that:

- The yield strength values show an anomalous behavior as a function of the temperature. From the room temperature until around $600{ }^{\circ} \mathrm{C}$, there occurs a decrease in the yield strength and a slight increase up to $700{ }^{\circ} \mathrm{C}$, decreasing sharply at temperatures above $700{ }^{\circ} \mathrm{C}$. In relation to the elongation, an anomaly is also present, with a significant decrease in the elongation at temperatures close to $600{ }^{\circ} \mathrm{C}$.

- In the tensile tests performed at temperatures between 200 and $700{ }^{\circ} \mathrm{C}$, it was possible to observe a serrated curve in the region of plastic deformation in the stress-strain curves. The stress-strain curve at $200{ }^{\circ} \mathrm{C}$ showed an A-type serration, while in the test temperature range around 400 and $700{ }^{\circ} \mathrm{C}$ it was observed that there was a B-type serration. In the tensile tests at $300^{\circ} \mathrm{C}$, a transition appears to occur, with a serrated A + B-type.

- In all specimens in which the Portevin-Le Chatelier effect was observed on the stress-strain curve (serrated) it can be noted that the fracture occurred on a macroscopic plane inclined at $45^{\circ}$ to the tensile axis.

- An intergranular cracking was observed in the specimen tensile tested at $500{ }^{\circ} \mathrm{C}$ which can be attributed to the decohesion of the carbides along the grain boundaries. The fracture surface of the specimen tensile tested at $700{ }^{\circ} \mathrm{C}$ showed the predominance of transgranular cracking with tear dimples with a parabolic shape. Several slip lines can be seen inside the grains and the presence of carbides along the grain boundaries.

- The values of $n=11.76$ and $Q c=407 \mathrm{~kJ} / \mathrm{mol}$ found in this work suggest that the dominant mechanism is dislocation creep. This significantly higher value of the activation energy was attributed to a high driving force, and the solute stops the grain boundary migration process operating within the alloy and may be related to the DSA effect present in Inconel 625. 
Author Contributions: Conceptualization: M.M.d.O., A.A.C. and R.B.; formal analysis: M.M.d.O., D.A.P.R. and N.B.d.L.; investigation: M.M.d.O., A.A.C., G.F.C.A. and R.B.; supervision, A.A.C.; validation: G.F.C.A., D.A.P.R., N.B.d.L, and R.B.; writing—original draft: A.A.C.; writing—review \& editing: G.F.C.A.

Funding: This research received no external funding.

Conflicts of Interest: The authors declare no conflict of interest.

\section{References}

1. Shankar, V.; Valsan, M.; Rao, K.B.S.; Mannan, S.L. Effects of temperature and strain rate on tensile properties and activation energy for dynamic strain aging in alloy 625. Metall. Mater. Trans. A Phys. Metall. Mater. Sci. 2004, 35A, 3129-3139. [CrossRef]

2. Korrapati, P.K.; Avasarala, V.K.; Bhushan, M.; Ramkumar, K.D.; Arivazhagan, N.N.; Narayanan, S. Assessment of Mechanical Properties of PCGTA Weldments of Inconel 625. Procedia Eng. 2014, 75, 9-13. [CrossRef]

3. Dokme, F.; Kulekci, M.K.; Esme, U. Microstructural and Mechanical Characterization of Dissimilar Metal Welding of Inconel 625 and AISI 316L. Metals 2018, 8, 797. [CrossRef]

4. Han, F.F.; Zhou, B.M.; Huang, H.F.; Leng, B.; Lu, Y.L.; Dong, J.S.; Li, Z.J.; Zhou, X.T. The tensile behavior of GH3535 superalloy at elevated temperature. Mater. Chem. Phys. 2016, 182, 22-31. [CrossRef]

5. Tian, C.; Cui, C.; Xu, L.; Gu, Y.; Sun, X. Dynamic strain aging in a newly developed Ni-Co-Base superalloy with low stacking fault energy. J. Mater. Sci. Technol. 2013, 29, 873-878. [CrossRef]

6. Chatterjee, A.; Sharma, G.; Tewari, R.; Chakravartty, J.K. Investigation of the Dynamic Strain Aging and Mechanical Properties in Alloy-625 with Different Microstructures. Metall. Mater. Trans. A 2015, 46, 1097-1107. [CrossRef]

7. Maj, P.; Zdunek, J.; Mizera, J.; Kurzydlowski, K.J.; Sakowicz, B.; Kaminski, M. Microstructure and strain-stress analysis of the dynamic strain aging in inconel 625 at high temperature. Met. Mater. Int. 2017, 23, 54-67. [CrossRef]

8. Maj, P.; Zdunek, J.; Gizynski, M.; Mizera, J.; Kurzydlowski, K.J. Statistical analysis of the Portevin-Le Chatelier effect in Inconel 718 at high temperature. Mater. Sci. Eng. A 2014, 619, 158-164. [CrossRef]

9. Yu, W.; Liu, S.; Wang, Y.; Sun, L. Recent Development in the Characteristics of Alloy 625 for A-USC Steam Turbine Casting. Energy Mater. 2017, 213-223. [CrossRef]

10. Zhang, Y.C.; Jiang, W.; Tu, S.T.; Zhang, X.C.; Ye, Y.J.; Wang, R.Z. Experimental investigation and numerical prediction on creep crack growth behavior of the solution treated Inconel 625 superalloy. Eng. Fract. Mech. 2018, 199, 327-342. [CrossRef]

11. American Society for Testing and Materials (ASTM) ASTM B443-00(2014). Standard Specification for Nickel-Chromium-Molybdenum-Columbium Alloy(UNS N06625) and Nickel-Chromium-Molybdenum-SiliconAlloy (UNS N06219) Plate, Sheet, and Strip; ASTM: West Conshohocken, PN, USA, 2014.

12. American Society for Testing and Materials (ASTM) ASTM E139-11. Standard Test Methods for Conducting Creep, Creep Rupture, and Stress Rupture Tests of Metallic Materials; ASTM: West Conshohocken, PN, USA, 2011.

13. Hrutkay, K.; Kaoumi, D. Tensile deformation behavior of a nickel based superalloy at different temperatures. Mater. Sci. Eng. A 2014, 599, 196-203. [CrossRef]

14. Hale, C.; Rollings, W.; Weaver, M. Activation energy calculations for discontinuous yielding in Inconel 718SPF. Mater. Sci. Eng. A 2001, 300, 153-164. [CrossRef]

15. Rahman, M.S.; Priyadarshan, G.; Raja, K.S.; Nesbitt, C.; Misra, M. Characterization of high temperature deformation behavior of INCONEL 617. Mech. Mater. 2009, 41, 261-270. [CrossRef]

16. Wright, J.K.; Carroll, L.J.; Cabet, C.; Lillo, T.M.; Benz, J.K.; Simpson, J.A.; Lloyd, W.R.; Chapman, J.A.; Wright, R.N. Characterization of elevated temperature properties of heat exchanger and steam generator alloys. Nucl. Eng. Des. 2012, 251, 252-260. [CrossRef]

17. Fournier, L.; Delafosse, D.; Magnin, T. Oxidation induced intergranular cracking and Portevin-Le Chatelier effect in nickel base superalloy 718. Mater. Sci. Eng. A 2001, 316, 166-173. [CrossRef]

18. Kaoumi, D.; Hrutkay, K. Tensile deformation behavior and microstructure evolution of Ni-based superalloy 617. J. Nucl. Mater. 2014, 454, 265-273. [CrossRef]

19. Mo, K.; Lovicu, G.; Chen, X.; Tung, H.M.; Hansen, J.B.; Stubbins, J.F. Mechanism of plastic deformation of a Ni-based superalloy for VHTR applications. J. Nucl. Mater. 2013, 441, 695-703. [CrossRef] 
20. Nalawade, S.A.; Sundararaman, M.; Kishore, R.; Shah, J.G. The influence of aging on the serrated yielding phenomena in a nickel-base superalloy. Scr. Mater. 2008, 59, 991-994. [CrossRef]

21. Lee, K.O.; Lee, S.B. Modeling of materials behavior at various temperatures of hot isostatically pressed superalloys. Mater. Sci. Eng. A 2012, 541, 81-87. [CrossRef]

22. Cottrell, A.H. LXXXVI. A note on the Portevin-Le Chatelier effect. London Edinburgh Dublin Philos. Mag. J. Sci. 1953, 44, 829-832. [CrossRef]

23. Nagesha, A.; Goyal, S.; Nandagopal, M.; Parameswaran, P.; Sandhya, R.; Mathew, M.D.; Mannan, S.K. Dynamic strain ageing in Inconel ${ }^{\circledR}$ Alloy 783 under tension and low cycle fatigue. Mater. Sci. Eng. A 2012, 546, 34-39. [CrossRef]

24. Sleeswyk, A.W. Slow strain-hardening of ingot iron. Acta Metall. 1958, 6, 598-603. [CrossRef]

25. Cuddy, L.; Leslie, W.C. Some aspects of serrated yielding in substitutional solid solutions of iron. Acta Metall. 1972, 20, 1157-1167. [CrossRef]

26. Cheng, J.; Nemat-Nasser, S. Model for experimentally-observed high-strain-rate dynamic strain aging in titanium. Acta Mater. 2000, 48, 3131-3144. [CrossRef]

27. Van Liempt, P.; Onink, M.; Bodin, A. Modelling the Influence of Dynamic Strain Ageing on Deformation Behaviour. Adv. Eng. Mater. 2002, 4, 225-232. [CrossRef]

28. McCormigk, P.G. A model for the Portevin-Le Chatelier effect in substitutional alloys. Acta Metall. 1972, 20, 351-354. [CrossRef]

29. Van den Beukel, A. Theory of the effect of dynamic strain aging on mechanical properties. Phys. Status Solidi 1975, 30, 197-206. [CrossRef]

30. Wycliffe, P.; Kocks, U.F.; Embury, J.D. On dynamic and static ageing in substitutional and interstitial alloys. Scr. Metall. 1980, 14, 1349-1354. [CrossRef]

31. Van Den Beukel, A.; Kocks, U.F. The strain dependence of static and dynamic strain-aging. Acta Metall. 1982, 30, 1027-1034. [CrossRef]

32. Estrin, Y.; McCormick, P.G. Modelling the transient flow behaviour of dynamic strain ageing materials. Acta Metall. Mater. 1991, 39, 2977-2983. [CrossRef]

33. Estrin, Y. A versatile unified constitutive model based on dislocation density evolution. In High Temperature Constitutive Modeling: Theory and Application; Freed, A.D., Walker, K.P., Eds.; American Society of Mechanical Engineers: New York, NY, USA, 1991; pp. 65-83.

34. Schlipf, J. Dislocation dynamics in strain aging alloys. Acta Metall. Mater. 1992, 40, 2075-2084. [CrossRef]

35. Gilat, A.; Wu, X. Plastic deformation of 1020 steel over a wide range of strain rates and temperatures. Int. J. Plast. 1997, 13, 611-632. [CrossRef]

36. Rodriguez, P. Serrated plastic flow. Bull. Mater. Sci. 1984, 6, 653-663. [CrossRef]

37. Rodriguez, P.; Venkadesan, S. Serrated Plastic Flow Revisited. Solid State Phenom. 1995, 42-43, $257-266$. [CrossRef]

38. Evans, R.W.; Wilshire, B. Introduction to Creep; The Institute of Materials: London, UK, 1993.

39. Ashby, M.F.; Frost, H.J. Deformation-mechanism Maps: The Plasticity and Creep of Metals and Ceramics; Pergamon Press: Oxford, UK, 1982.

40. Moore, I.J.; Taylor, J.I.; Tracy, M.W.; Burke, M.G.; Palmiere, E.J. Grain coarsening behaviour of solution annealed Alloy 625 between $600-800{ }^{\circ}$ C. Mater. Sci. Eng. A 2017, 682, 402-409. [CrossRef]

41. Caliari, F.R.; Candioto, K.C.G.; Couto, A.A.; Nunes, C.Â.; Reis, D.A.P. Effect of Double Aging Heat Treatment on the Short-Term Creep Behavior of the Inconel 718. J. Mater. Eng. Perform. 2016, 25, 2307-2317. [CrossRef]

42. Rodriguez, R.; Hayes, R.W.; Berbon, P.B.; Lavernia, E.J. Tensile and creep behavior of cryomilled Inco 625. Acta Mater. 2003, 51, 911-929. [CrossRef]

43. Sun, F.; Gu, Y.F.; Yan, J.B.; Zhong, Z.H.; Yuyama, M. Phenomenological and microstructural analysis of intermediate temperatures creep in a Ni-Fe-based alloy for advanced ultra-supercritical fossil power plants. Acta Mater. 2016, 102, 70-78. [CrossRef]

(C) 2019 by the authors. Licensee MDPI, Basel, Switzerland. This article is an open access article distributed under the terms and conditions of the Creative Commons Attribution (CC BY) license (http:/ / creativecommons.org/licenses/by/4.0/). 